POLITYKA ENERGETYCZNA - ENERGY POLICY JOURNAL

$2021 \uparrow$ Volume $24 \uparrow$ Issue $1 \uparrow 85-100$

DOI: $10.33223 / \mathrm{epj} / 134144$

Olha Prokopenko ${ }^{1}$, Anna Chechel $^{2}$, Iryna SotnYK $^{3}$, Vitaliy OMElyanenko ${ }^{4}$, Tetiana Kurbatova ${ }^{5}$, Tetiana $\mathrm{NYCH}^{6}$

\title{
Improving state support schemes for the sustainable development of renewable energy in Ukraine
}

ABSTRACT: The world prefers to increase energy efficiency and use energy from renewable and alternative sources. Ukraine has chosen the same path. To form recommendations for improving state support schemes for the sustainable development of renewable energy, the authors conducted a thorough analysis of the state of renewable energy in Ukraine and its legislative support. The advantage of the study is the visual presentation of data. Thus, the authors presented and analyzed which energy sources Ukraine uses for its own needs, the essence of the Ukrainian energy balance and its state in 2019. The authors found that the development of renewable energy is one of the "Sustainable Development Goals of Ukraine", which are based on the world. The authors noted the objectives and

$\triangle$ Corresponding Author: Olha Prokopenko; e-mail: prokopenko.olha.w@gmail.com

1 International Humanitarian University, Odessa, Ukraine; ORCID iD: 0000-0003-1362-478X; e-mail: prokopenko. olha.w@gmail.com

2 Donetsk State University of Management, Mariupol, Ukraine; ORCID iD: 0000-0003-4307-5574; e-mail: annachechel.ac@gmail.com

3 Sumy State University, Sumy, Ukraine; ORCID iD: 0000-0001-5787-2481; e-mail: insotnik@gmail.com

4 Institute of Industrial Economics of National Academy of Sciences of Ukraine, Kyiv, Ukraine; Sumy State University, Sumy, Ukraine; ORCID iD: 0000-0003-0713-1444; e-mail: v.omelyanenko@i.ua

5 Sumy State University, Sumy, Ukraine; ORCID iD: 0000-0001-6891-443X; e-mail: t.kurbatova@ukr.net

6 Taras Shevchenko National University of Kyiv Ukraine, Kyiv, Ukraine; ORCID iD: 0000-0003-3842-2009; e-mail: t.nych@gmail.com 
indicators of the goal, assessed the value of the indicators and found that, even though the goal is one of the most important goals because it is in third place in the number of amendments to existing regulations, there is a lag in plans and more lag on some additional tasks. The authors systematized the legal basis for the functioning of renewable energy and revealed this process' subject-object relations. The analysis showed that the improvement of state support schemes for the sustainable development of renewable energy should be based on European norms and standards but consider national specifics. The authors proposed and described the principles of improving state support for the sustainable development of renewable energy, which should be based on ensuring the balance of interests of the three main stakeholders of the renewable energy market: the state, energy consumers and investors.

KEYWORDS: energy, energy balance indicators, renewable energy, state support, sustainable development, Sustainable Development Goals

\section{Introduction}

There are changes in the world's approaches to energy policy: the transition from an outdated model of the energy sector, dominated by large producers, fossil fuels, inefficient networks, imperfect competition in the markets of natural gas, electricity, coal to a new model in which a more competitive environment is created, opportunities for development are equalized, and the dominance of one of the types of energy production or sources and/or ways of fuel supply is minimized (Karimi and Vaez-Zadeh 2020; Siniša 2020; Vivanco 2017).

At the same time, preference is given to improving energy efficiency and the use of energy from renewable and alternative sources (Kharazishvili et al. 2020). Implementing measures to prevent and adapt to climate change is also one of the priorities of global energy development (Bashynska and Dyskina 2018; Sotnyk et al. 2020). This poses new economic and technological challenges for Ukraine, but at the same time opens new opportunities for finding and implementing innovative developments in mining, fossil fuel processing, production, transformation, supply and consumption of energy, which necessitates the formation of a new energy policy.

In recent years, many scientists have studied state support for renewable energy, in particular (Kumar and Majid 2020) note that strong states support, have developed policies, programs and a liberal environment to attract foreign investments, and the increasingly favorable economic situation has pushed India to one of the leading leaders in the most attractive renewable energy markets in the world.

The importance of the role of government is noted in other works, namely the need to build partnerships based on integrated and cooperative approaches and based on practical experience (Jefferson 2000); support schemes, which are technology-specific, and those that avoid unnecessary risks in project revenues, are more effective and efficient than technology-neutral support schemes, or schemes with higher revenue risk (Ragwitz and Steinhilber 2014). 
Scientists (Poullikkas et al. 2012) carried out significant research on European public support schemes for renewable energy, which dealt with investment support, feed-in tariffs, tradable green certificates, and fiscal and financial measures which the Member States have adopted for the promotion of RES technologies. The described technologies can be partially applied for Ukraine, but there is no ready-made solution; therefore, the purpose of the article is to study the best practices and develop directions for improving state support for the sustainable development of renewable energy.

\section{Data and legislative analysis}

\subsection{Data analysis}

Ukraine uses various energy sources for its own needs, such as oil, natural gas, coal, nuclear and hydropower, wind and solar energy, etc. The main renewable sources are hydroenergy, energy of biofuels and wastes and wind and solar energy (Fig. 1).

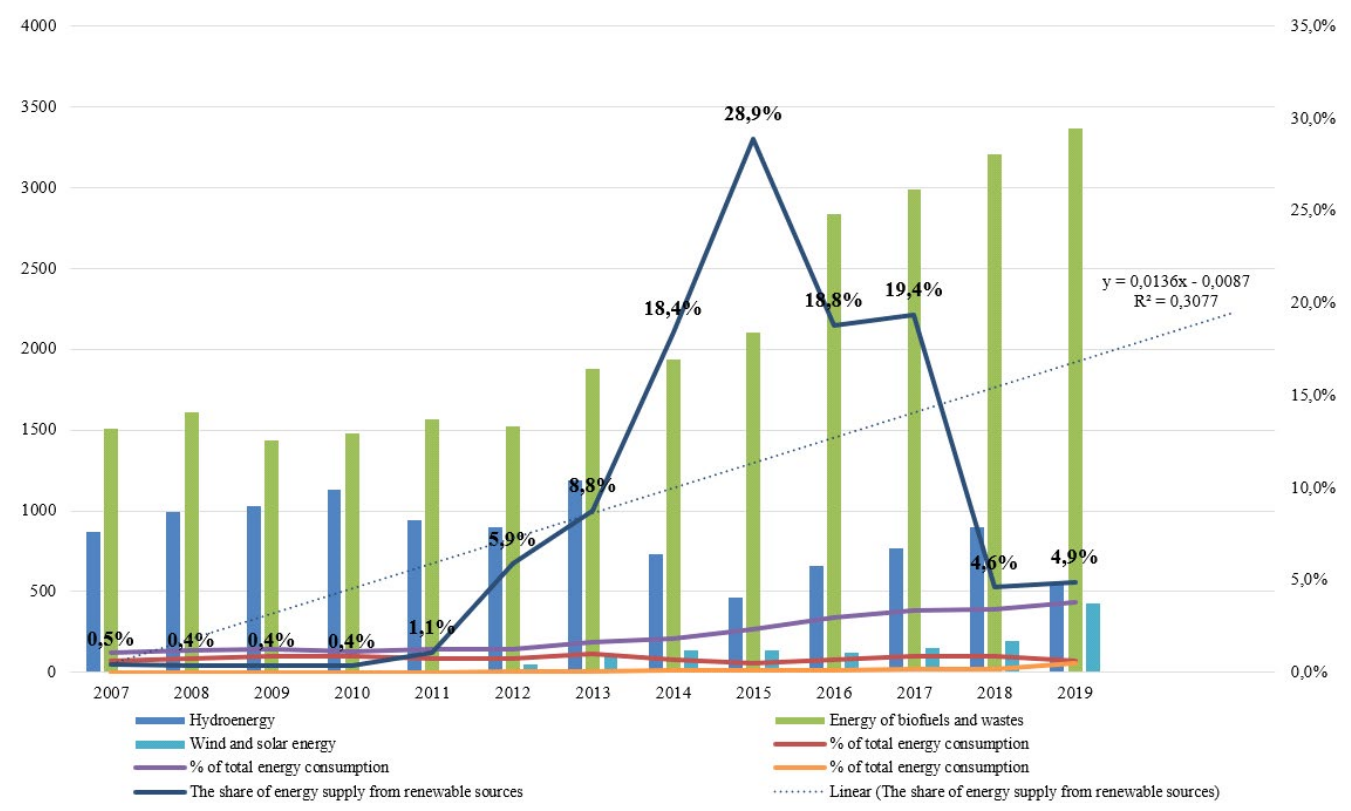

Fig. 1. Energy consumption from renewable sources for 2007-2019 in Ukraine and the forecast Source: own study based on (State Statistics Service of Ukraine 2021a)

Rys. 1. Zużycie energii ze źródeł odnawialnych na Ukrainie w latach 2007-2019 i prognoza 
The main means of determining the real level of fuel and energy resources, analysis of their dynamics, formation and implementation of effective state policy in meeting the needs of the national economy in fuel and energy resources, protection of national foreign policy and foreign economic interests taking global energy trends into account is a system of development (formation), monitoring, economic analysis and forecasting of the energy balance of Ukraine.

Energy balance - a system of indicators that reflects the quantitative equality between income and energy consumption and characterizes the structure of energy production and use in the economy, the ratio between fuel demand within the relevant territorial or production unit (country, region, industry, enterprise, etc.) and its use for a certain period. In 2019, Ukraine's energy balance looked like this (Fig. 2).

As you can see, own production of energy resources in 2019 is $63.4 \%$. Final consumption accounts for $52 \%$ of electricity: the household sector uses $14.8 \%$ of all electricity, industry $-17 \%$.

Traditionally, fossil resources are the most popular in Ukraine today: natural gas and coal, which together account for more than $60 \%$ of the domestic energy balance. Simultaneously, in recent years, due to changes in prices, technologies and global trends, the share of other types of energy in consumption is gradually increasing. Besides, today, there is reason to expect their further growth with a corresponding decrease in the share of fossil fuels in the country's energy balance. The availability of all these resources in Ukraine, the creation of a competitive market environment and conditions for the systematic development of the resource base for nuclear energy, modernization of generating capacity and replacement of raw materials with alternative fuels, further exploration and production of hydrocarbons, including unconventional, and the more efficient use of potential in the field of renewable energy will contribute to the gradual strengthening of Ukraine's position in the rational production of energy and its economical consumption.

The sustainable development of renewable energy - is one of the "Sustainable Development Goals" (namely, goal № 7. Available and clean energy). The "Sustainable Development Goals" (SDGs, also known as the Global Goals) are critical areas for the development of the countries approved at the UN Summit on Sustainable Development (Buonocore et al. 2019). They replaced the Millennium Development Goals, which expired at the end of 2015. The SDGs have been approved for 2015 to 2030 and have 17 Global Goals, which meet 169 goals.

The official document (Resolution) of the UN General Assembly is called Transforming our world: the 2030 Agenda for Sustainable Development, adopted on September 25, 2015, and announced a new action plan aimed at bringing the world on the trajectory of sustainable development (United Nations 2015). Almost every country adapted common goals to national ones, including and Ukraine (MEDTU 2017). Goal № 7 in the national strategy has the following objectives and indicators (Table 1).

The target values of the indicators are set at the following levels (Fig. 3).

Figure 2 shows the lag in goals, and even more lag in some tasks is expected (Fig. 4).

Energy resources production in Ukraine has been declining since 2012. In particular, in 2015, electricity was generated by $10.2 \%$ less than in 2014 (163.3 billion $\mathrm{kWh}$ ). Since 2014, there has been a decrease in domestic primary energy production, a decrease in Russia's imports, and a reorientation to imports from other countries. 

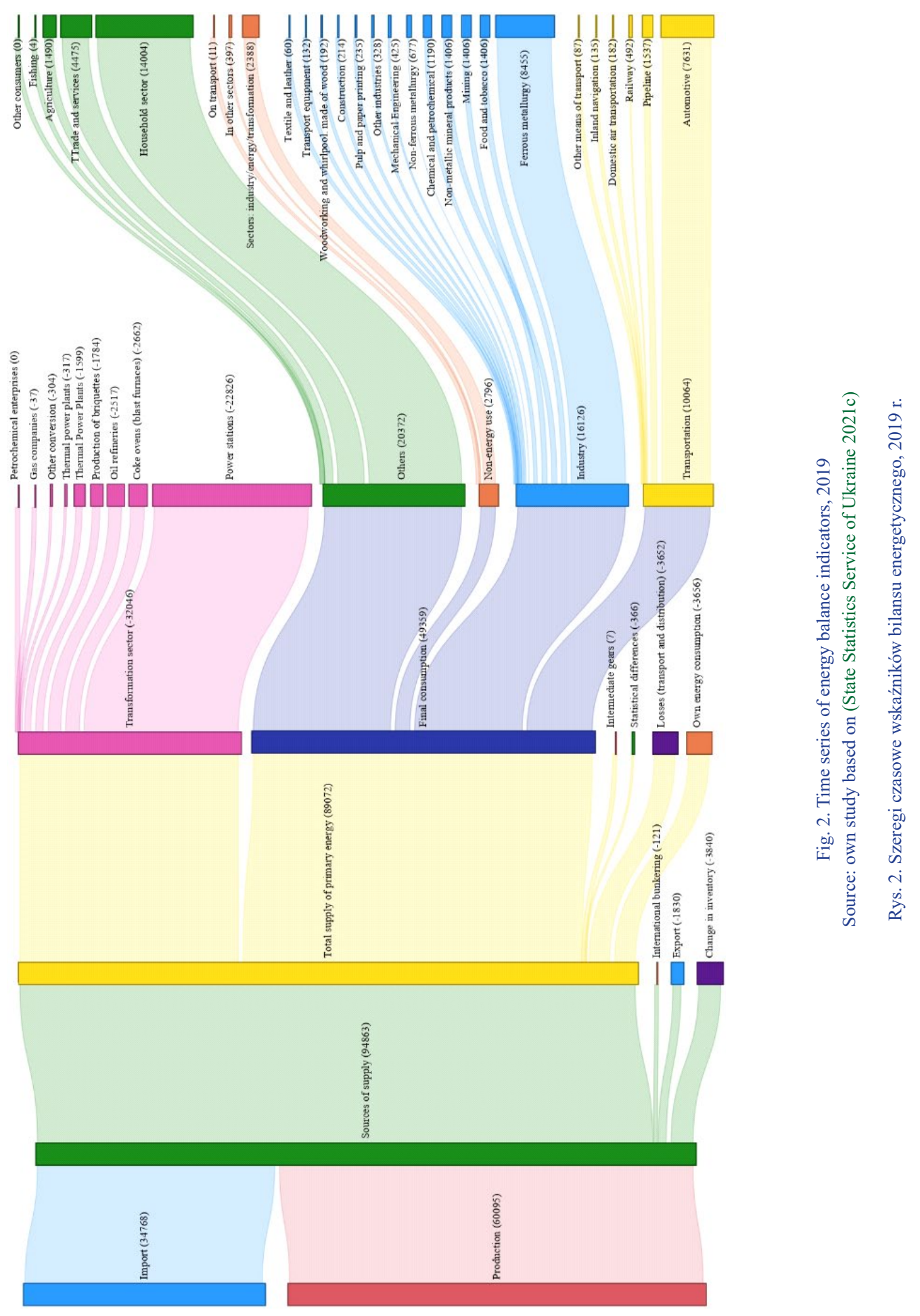
TABLE 1. Tasks and indicators Goal № 7

TABELa 1. Zadania i wskaźniki Celu nr 7

\begin{tabular}{|c|c|}
\hline Task & Indicator \\
\hline \multirow{3}{*}{$\begin{array}{l}\text { Task 7.1. Expand infrastructure and modernize networks } \\
\text { to ensure reliable and sustainable energy supply through } \\
\text { the introduction of innovative technologies }\end{array}$} & Indicator 7.1.1. Electricity generation [billion $\mathrm{kWh}$ ] \\
\hline & $\begin{array}{l}\text { Indicator } 7.1 .2 . \text { Technological costs of electricity in } \\
\text { distribution networks [\%] }\end{array}$ \\
\hline & Indicator 7.1.3. Heat losses in heating networks [\%] \\
\hline \multirow[t]{2}{*}{$\begin{array}{l}\text { Task } 7.2 . \text { Ensure diversification of the supply of primary } \\
\text { energy resources }\end{array}$} & $\begin{array}{l}\text { Indicator } 7.2 .1 \text {. Maximum share of imports of primary } \\
\text { energy resources (except nuclear fuel) from one country } \\
\text { (company) in the total volume of their supply (imports) } \\
{[\%]}\end{array}$ \\
\hline & $\begin{array}{l}\text { Indicator } 7.2 .2 . \text { Share of one supplier in the nuclear fuel } \\
\text { market }[\%]\end{array}$ \\
\hline $\begin{array}{l}\text { Task 7.3. Increase the share of energy from renewable } \\
\text { sources in the national energy balance, in particular } \\
\text { through the introduction of additional capacity of } \\
\text { facilities producing energy from renewable sources }\end{array}$ & $\begin{array}{l}\text { Indicator } 7.3 .1 \text {. The share of energy produced from } \\
\text { renewable sources in total final energy consumption [\%] }\end{array}$ \\
\hline Task 7.4. Increase the energy efficiency of the economy & $\begin{array}{l}\text { Indicator 7.4.1. Energy intensity of GDP (primary } \\
\text { energy consumption per unit of GDP) }[\mathrm{kg} \text { in oil } \\
\text { equivalent per } \$ 1 \mathrm{USA}]\end{array}$ \\
\hline
\end{tabular}

The approved Energy Strategy until 2030 to meet the needs of economic growth provides for the extensive development of fuel and energy, primarily through the construction of new energy facilities (nuclear power plants, uranium ore mining, nuclear fuel production and storage of radioactive waste, thermal power plants, PSP, development of shale gas fields, etc.). The energy sector needs significant reform, which aims to ensure consumers' interests by establishing adequate pricing mechanisms, connecting consumers to networks, and the transparent charging of services in accordance with the principles of the Third Energy Package. To do this, it is necessary to adjust prices to an economically reasonable level for all categories of consumers, overcome the non-transparency of Ukrainian energy companies' business, and open the energy market for European corporations under fair competition conditions.

We can say that Goal 7 is among the TOP-3 most important goals for the government because it is in third place in terms of the number of amendments to existing regulations (Fig. 5).

There are changes in the world's approaches to energy policy: the transition from the outdated model of the energy sector, which was dominated by large producers, fossil fuels, inefficient networks, imperfect competition in the markets of natural gas, electricity, coal - to a new model in which a more competitive environment is created, opportunities for development are equalized, and the dominance of one of the types of energy production or sources and/or ways of fuel supply is minimized. At the same time, preference is given to improving energy efficiency and the use of energy from renewable and alternative sources. Implementing measures to prevent and adapt to climate change is also one of the global energy development priorities (Miśkiewicz 2018; Prokopenko and Miśkiewicz 2020). 


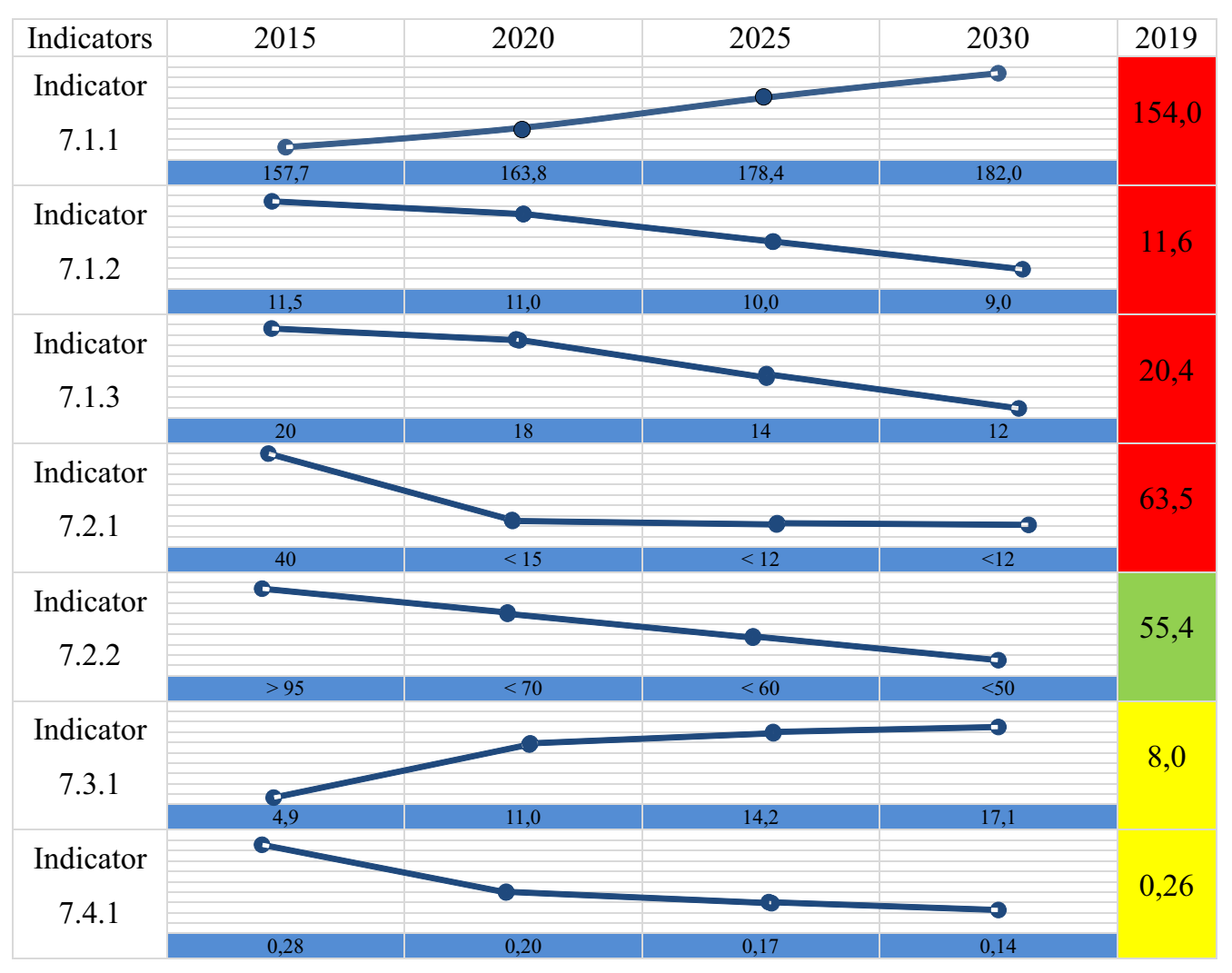

Fig. 3. Target values of indicators in SDG 17 for Ukraine Source: own study based on (MEDTU 2017)

Rys. 3. Docelowe wartości wskaźników w SDG 17 dla Ukrainy

Ukraine has chosen the same path: «The Concept of "green" Energy Transition of Ukraine Until 2050» is a document that outlines the strategic guidelines for the development of the fuel and energy complex of Ukraine for the period up to 2050 (MEEP 2020).

Implementing the Concept's objectives will require somewhat different approaches to energy regulation, based on the fundamental principles adopted by EU countries, to the development of strategic planning documents and practical activities for the implementation of state policy in the energy sector. Thus, the improvement of state support schemes for the sustainable development of renewable energy is significant today. 


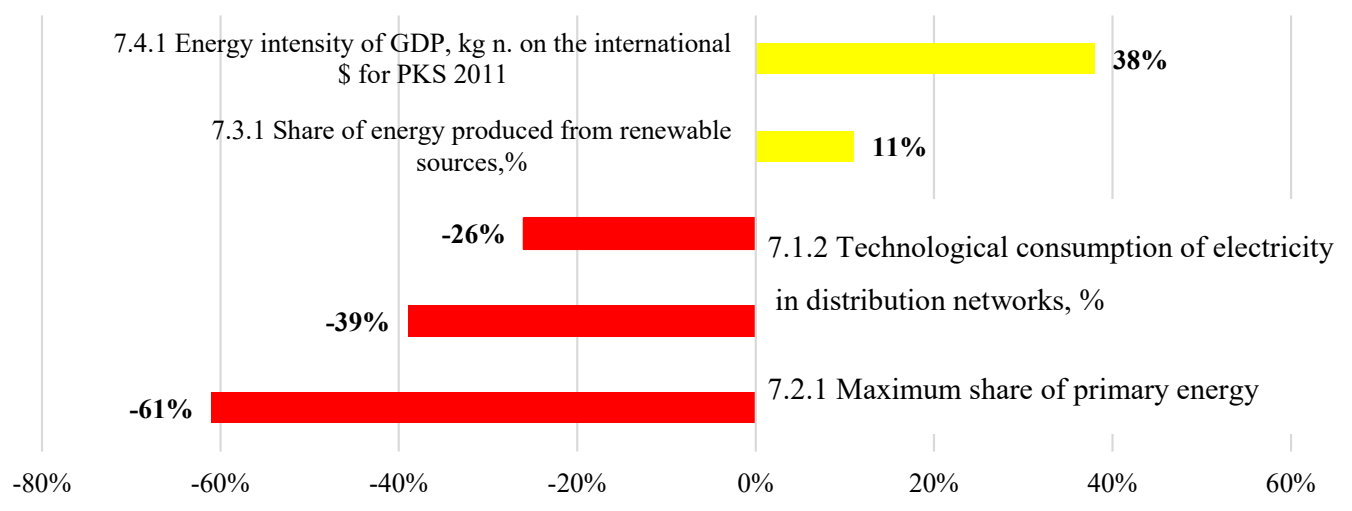

Fig. 4. Assessment of progress towards Goal 7 in Ukraine (according to the methodology of the United Nations Economic and Social Commission for Asia and the Pacific (UNESCAP))

Source: own study based on (State Statistics Service of Ukraine 2021b)

Rys. 4. Ocena postępów w osiąganiu Celu 7 na Ukrainie (zgodnie z metodologią Komisji Ekonomiczno-Społecznej ONZ ds. Azji i Pacyfiku (UNESCAP))

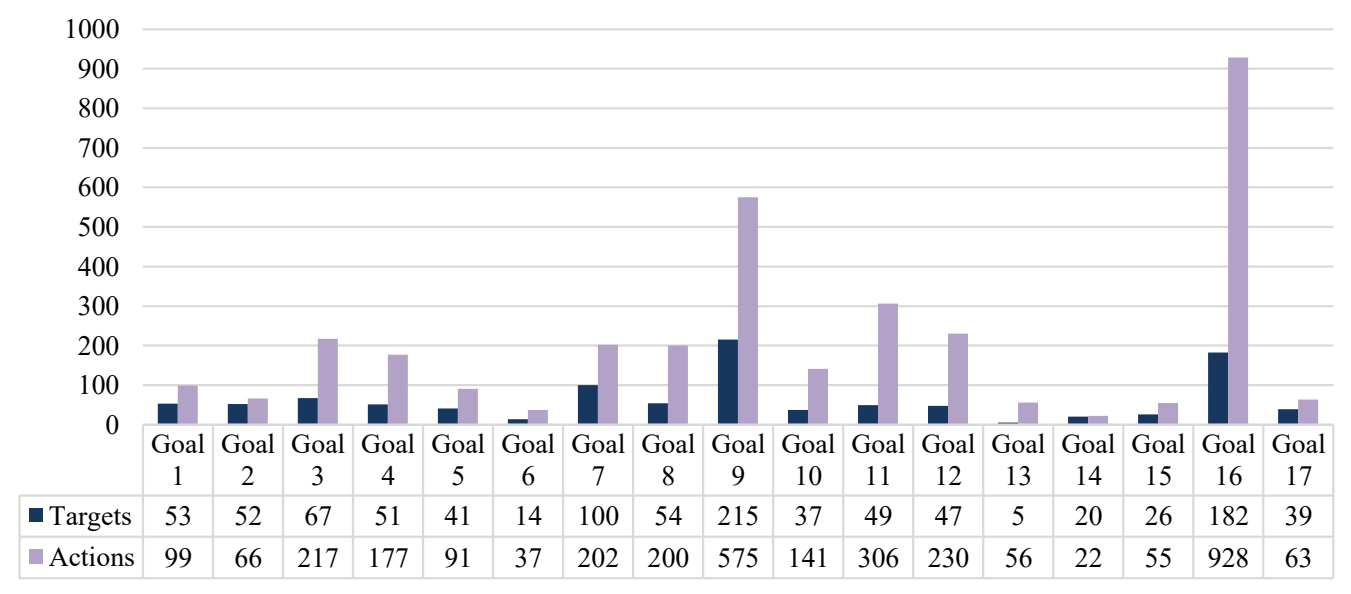

Fig. 5. Status of SDG incorporation into current national strategic and policy documents

Source: own study based on (UNDP Ukraine 2020)

Rys. 5. Stan włączenia SDG do aktualnych krajowych dokumentów strategicznych i politycznych 


\subsection{Analysis of legislation on renewable energy in Ukraine}

The legal basis for the operation of renewable energy is the Constitution of Ukraine and the Law of Ukraine "On Alternative Fuels", "On Alternative Energy Sources", "On Amendments to Certain Laws of Ukraine to Improve Support for Electricity Production from Alternative Energy Sources", "On Ukraine's Accession to the Statute of the International Renewable Energy Agency (IRENA)", "On Amendments to Certain Laws of Ukraine Concerning Ensuring Competitive Conditions for Electricity Production from Alternative Energy Sources" and others.

Regulatory and legal support is systematized in Table 2.

TABLE 2. Systematization of regulatory and legal support in the field of renewable energy

TABELA 2. Systematyzacja regulacji prawnych i wsparcie prawne na płaszczyźnie energii odnawialnej

\begin{tabular}{|c|c|}
\hline Document & Substantive provisions \\
\hline 1 & 2 \\
\hline Constitution of Ukraine & Provisions on the right of citizens to a safe ecological environment \\
\hline $\begin{array}{l}\text { Law of Ukraine „On Electricity” } \\
\text { of 10/16/1997 № 575/97-Vr }\end{array}$ & $\begin{array}{l}\text { It provides for establishing a ,green” tariff, which is used to purchase } \\
\text { electricity generated at electricity facilities, including from alternative } \\
\text { renewable energy sources. }\end{array}$ \\
\hline $\begin{array}{l}\text { Law of Ukraine „On Alternative Fuels” } \\
\text { of 1/14/2000 № 1391-XIV }\end{array}$ & $\begin{array}{l}\text { Determines the legal, economic, environmental and organizational } \\
\text { principles of using alternative energy sources and promoting their } \\
\text { expansion in the fuel and energy sector. }\end{array}$ \\
\hline $\begin{array}{l}\text { Law of Ukraine „On Alternative Energy } \\
\text { Sources” of 2/20/2003 № 555-IV }\end{array}$ & $\begin{array}{l}\text { Defines the legal, economic, environmental and organizational principles } \\
\text { for the use of alternative energy sources, including renewable sources } \\
\text { and the promotion of their expanded use. It is planned to stimulate } \\
\text { electricity producers from alternative energy sources, which have } \\
\text { acquired the right to support as a result of the auction. }\end{array}$ \\
\hline $\begin{array}{l}\text { Law of Ukraine „On combined heat and } \\
\text { power (cogeneration) and use of waste } \\
\text { energy potential” from 4/5/2005 } \\
\text { № } 2509 \text {-IV }\end{array}$ & $\begin{array}{l}\text { It provides for the creation of legal bases to increase fuel efficiency } \\
\text { in energy production processes or other technological processes, } \\
\text { development and application of combined heat and power generation } \\
\text { technologies, increase the reliability and security of energy supply at the } \\
\text { regional level, and attract investment cogeneration. }\end{array}$ \\
\hline $\begin{array}{l}\text { Law of Ukraine „On energy lands } \\
\text { and the legal regime of special zones } \\
\text { of energy facilities” dated 7/9/2010 } \\
\text { № } 2480 \text {-VI }\end{array}$ & $\begin{array}{l}\text { Defines the legal and organizational basis for the provision and use of } \\
\text { land for the location of facilities, including alternative energy facilities } \\
\text { that use renewable energy sources, regardless of the purpose of such } \\
\text { land. }\end{array}$ \\
\hline $\begin{array}{l}\text { Law of Ukraine „On Ratification of } \\
\text { the Protocol of Accession of Ukraine } \\
\text { to the Treaty establishing the Energy } \\
\text { Community” of 12/15/2010 № 2787-VI }\end{array}$ & $\begin{array}{l}\text { On February } 1,2011 \text {, Ukraine became a full member of the Energy } \\
\text { Community and undertook implementing the acquis communautaire into } \\
\text { national law. }\end{array}$ \\
\hline $\begin{array}{l}\text { Law of Ukraine „On Amendments to } \\
\text { Certain Laws of Ukraine on Ensuring } \\
\text { Competitive Conditions for Production } \\
\text { of Electricity from Alternative Energy } \\
\text { Sources” of June 4, 2015, № 514-VIII }\end{array}$ & $\begin{array}{l}\text { The state stimulates the development of renewable energy in the form } \\
\text { of a ,green” tariff. The list of business entities covered by incentive } \\
\text { measures has been expanded. }\end{array}$ \\
\hline
\end{tabular}




\begin{tabular}{|c|c|}
\hline 1 & 2 \\
\hline $\begin{array}{l}\text { Law of Ukraine „On Ratification } \\
\text { of the Paris Agreement” of 7/14/2016 } \\
\text { № 1469-VIII }\end{array}$ & $\begin{array}{l}\text { It envisages the development of Ukraine's economy taking into } \\
\text { account the reduction of greenhouse gas emissions. }\end{array}$ \\
\hline $\begin{array}{l}\text { Law of Ukraine „On the National } \\
\text { Commission for State Regulation } \\
\text { of Energy and Utilities” of 9/22/2016 } \\
\text { № } 1540 \text {-VIII }\end{array}$ & $\begin{array}{l}\text { Determines the National Commission for State Regulation of Energy } \\
\text { and Utilities' legal status, its tasks, functions, powers, and procedure } \\
\text { for their implementation. One of the Commission's main tasks is to } \\
\text { promote the implementation of energy efficiency measures, increase } \\
\text { the share of energy production from renewable energy sources, } \\
\text { and environmental protection. }\end{array}$ \\
\hline $\begin{array}{l}\text { Law of Ukraine „On Ukraine’s accession } \\
\text { to the Charter of the International } \\
\text { Renewable Energy Agency (IRENA)” } \\
\text { of 12/5/2017 № } 2222 \text {-VIII }\end{array}$ & Ukraine's accession to the International Renewable Energy Agency. \\
\hline $\begin{array}{l}\text { Law of Ukraine „On the electricity market” } \\
\text { from 4/13/2017 № 2019-VIII }\end{array}$ & $\begin{array}{l}\text { The law is based on the electricity market principles, one of which is } \\
\text { to promote the development of alternative and renewable energy. It } \\
\text { also provides that producers using alternative energy sources should } \\
\text { be given priority. It is possible to conclude long-term contracts for } \\
\text { the purchase of electricity produced at the ,green" tariff, until } 2030 \text {, } \\
\text { as well as the conclusion of a contract of sale of electricity between } \\
\text { the guaranteed buyer and the entity that produces electricity from } \\
\text { alternatives, including renewable, energy sources and the results } \\
\text { of the auction, acquired the right to support. }\end{array}$ \\
\hline $\begin{array}{l}\text { Law of Ukraine „On Amendments to } \\
\text { Certain Laws of Ukraine on Ensuring } \\
\text { Competitive Conditions for Electricity } \\
\text { Production from Alternative Energy } \\
\text { Sources” of April 25, 2019, № 2712-VIII }\end{array}$ & $\begin{array}{l}\text { The law regulates the urgent problems of ,green" electricity } \\
\text { generation, which will reduce the financial burden on the final price } \\
\text { of electricity by optimizing the level of ,green" tariff, achieving } \\
\text { a balance of interests of society, electricity consumers and electricity } \\
\text { market participants and improve the solvency of market participants } \\
\text { at the same time further development of renewable energy. }\end{array}$ \\
\hline
\end{tabular}

Source: own study based on (Doronina 2020; Kuzmina 2016; Stoyan 2014).

To understand the essence and content of state support for the sustainable development of renewable energy it is necessary to reveal this process' subject-object relations. Subjects of state regulation (including support) of the economy (including renewable energy) are the subjects of execution (the state and its institutional bodies: legislative, executive, judicial bodies of different levels) and subjects of influence (public and political connections, mass media, individuals). Objects of state regulation of the economy are areas, industries, regions, as well as phenomena, situations and conditions of socio-economic life of the country where problems have arisen or may arise that are not solved automatically or immediately, as required by the normal functioning of the economy and social maintenance stability.

In our opinion, the objects of state regulation of sustainable development of renewable energy should be considered:

$\downarrow$ the sphere of renewable energy sources - an area of activity related to the use of renewable energy sources for the production, supply, transportation, storage, transmission and consumption of energy produced from renewable sources; 
$\checkmark$ investment and innovation processes in the industry;

$\downarrow$ competitive environment and the level of monopolization of the energy market;

$\checkmark$ renewable energy prices; the structure of the renewable energy market;

$\checkmark$ the impact of renewable energy on the environment and the welfare of society, etc.

In turn, sustainable development was described by the 1987 Bruntland Commission Report as "development that meets the needs of the present without compromising the ability of future generations to meet their own needs" (United Nations 1987).

The introduction of European norms and standards - the acquis Communautaire - in the energy sector, as well as in the field of environmental protection allows our country to gradually restructure the economy and embark on the path of sustainable development.

Thus, the improvement of state support schemes for sustainable development of renewable energy should be based on European norms and standards, but take national specifics into account.

\section{Results and discussion}

Within the framework of the conducted research, we have singled out the following directions of improvement of the state support of sustainable development of renewable energy (Fig. 6). The basis of state support for sustainable development of renewable energy should be to ensure the balance of interests of the 3 main stakeholders of the renewable energy market: the state, energy consumers and investors.

Based on the analysis of scientific papers on public administration, it can be noted that the methods of state regulation of the economy, in particular the development of renewable energy, include the following:

$\checkmark$ legal, based on legislative and regulatory instruments;

$\checkmark$ administrative, which are based on the application of administrative acts and procedures that are binding;

$\checkmark$ organizational and economical, which provide for the organization of the activities of regulatory entities by creating conditions by the state, the implementation of which makes such activities economically viable, while the state influences the activities of regulatory entities through the use of economic means;

$\checkmark$ socio-psychological, which are based on the openness of information about the state of a particular sector of government and broad participation of society in the activities of the subject of regulation and provide explanation and promotion of specific ideas, influence on the interests of certain social groups, status in society, social conditions their livelihoods and opportunities for self-realization.

The balance of interests of stakeholders, the use of these methods and tools will form a concerted action of all participants in the renewable energy sector to ensure the most favorable 


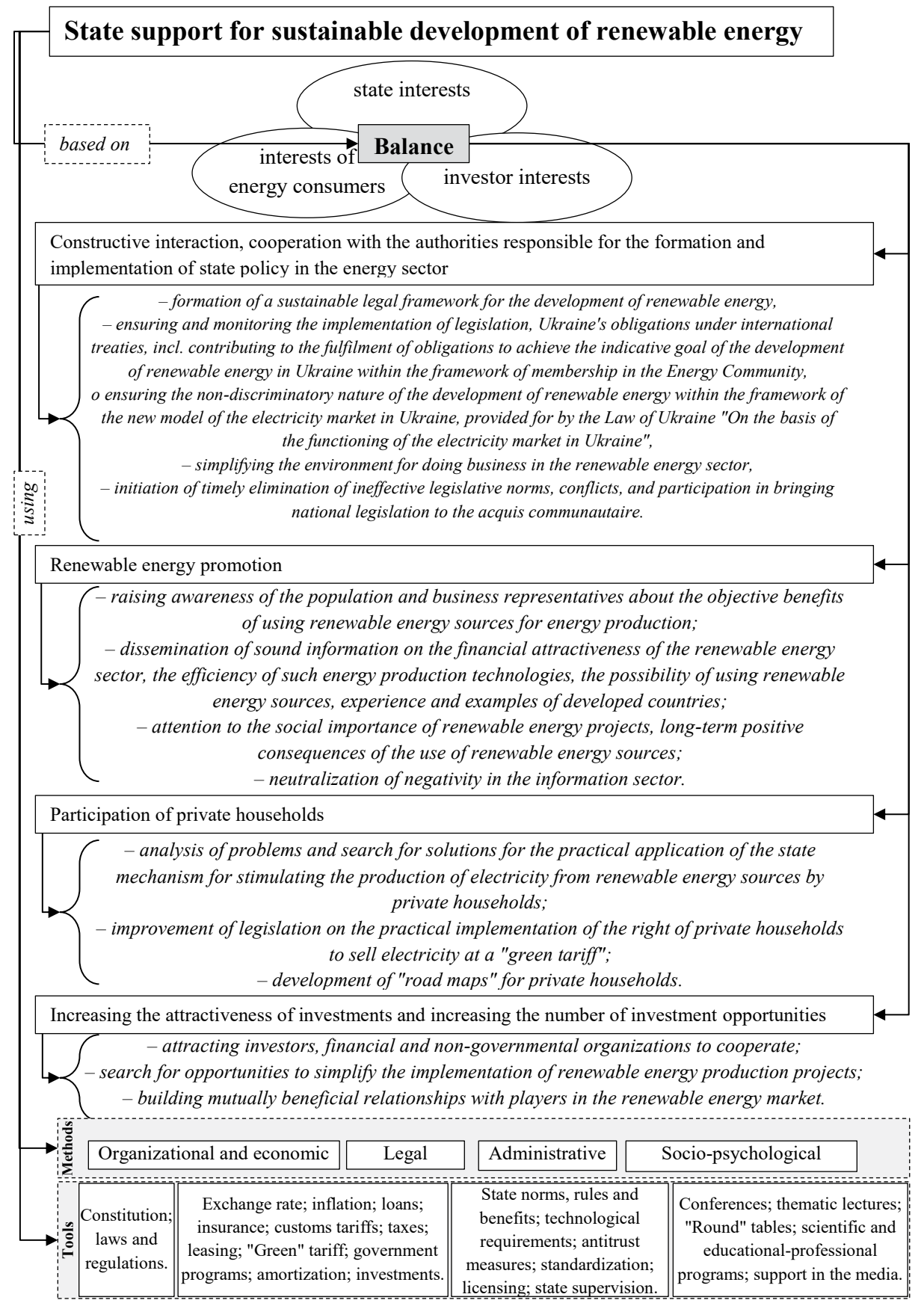

Fig. 6. Improving state support for sustainable development of renewable energy Source: own study

Rys. 6. Poprawa wsparcia państwa dla zrównoważonego rozwoju energetyki odnawialnej 
conditions for doing business in the field of renewable energy, support the implementation of renewable energy strategy in Ukraine and achieve energy independence.

\section{Conclusions}

Thus, based on the research, it can be concluded that only by ensuring the implementation at the state level of the above goals, principles, methods and schemes of state support for sustainable development of renewable energy, new opportunities will open up to ensure the required level of Ukraine's energy security and energy independence. The jumps in prices for most energy sources and significant supply disruptions, dictated by political problems, have demonstrated the country's modern energy system's weakness. At the same time, renewable energy sources can compensate for the shortcomings of the existing system, because the energy reserves of the sun, water and wind are almost unlimited. Also, carbon emissions will be reduced, as renewable energy sources significantly reduce $\mathrm{CO}_{2}$ emissions. Virtually every Ukraine region can and should effectively use at least one alternative energy source: biomass, water, wind, geothermal and solar energy.

However, renewables have their drawbacks, as solar and wind power are not permanent sources and do not solve system reliability. In further studies, the authors plan to consider the world experience of introducing remuneration in the capacity market to improve energy security in power systems in more detail (for example, the capacity market in the UK and Poland, a strategic reserve in Germany).

The publication was prepared in the framework of the research project № 2020.01/0135 "Formation of economic mechanisms for sustainable development of renewable energy in the conditions of global and local threats to energy security of Ukraine", funded by the National Research Foundation of Ukraine

\section{References}

BASHYNSKA, I. and DyskinA, A. 2018. The overview-analytical document of the international experience of building smart city. Business: Theory and Practice 19, pp. 228-241, DOI: 10.3846/btp.2018.23.

Buonocore et al. 2019 - Buonocore, J.J., Choma, E., Villavicencio, A.H. et al. 2019. Metrics for the sustainable development goals: renewable energy and transportation. Palgrave Commun 5, 136, DOI: 10.1057/s41599-019-0336-4.

Doronina, I. 2020. Regulatory and legal support of development renewable energy in Ukraine (Normatyvno-pravove zabezpechennia rozvytku vidnovliuvanoi enerhetyky $v$ Ukraini). Public Administration and Local Government (Derzhavne upravlinnia ta mistseve samovriaduvannia) 1(44), pp. 31-43, DOI: 10.33287/102005 (in Ukrainian). 
JEFFERSON, M. 2000. Energy policies for sustainable development in book: World energy assessment - Energy and the challenge of sustainability. UNDP, pp. 416-452.

Karimi, M.J. and Vaez-ZadeH, S. 2020. An Agent-Based Model for Electric Energy Policy Assessment. Electric Power Systems Research 192(10), 106903, DOI: 10.1016/j.epsr.2020.106903.

Kharazishvili et al. 2020 - Kharazishvili, Y., Kwilinski, A., Grishnova, O. and Dzwigol, H. 2020. Social Safety of Society for Developing Countries to Meet Sustainable Development Standards: Indicators, Level, Strategic Benchmarks (with Calculations Based on the Case Study of Ukraine). Sustainability 12(21), 8953, DOI: 10.3390/su12218953.

Kumar, J., C.R. and MaJiD, M.A. 2020. Renewable energy for sustainable development in India: current status, future prospects, challenges, employment, and investment opportunities. Energy, Sustainability and Society 10(2), DOI: 10.1186/s13705-019-0232-1.

Kuzmina, M. 2016. Systematization of legislation in the field of renewable energy (Systematyzatsiia zakonodavstva u sferi vidnovliuvalnoi enerhetyky). Economic theory and law (Ekonomichna teoriia ta pravo) 2, pp. 122-132 (in Ukrainian).

Law of Ukraine "On Alternative Energy Sources" 2003. [Online] https://zakon.rada.gov.ua/laws/show/55515\#Text [Accessed: 2020-11-23].

MEDTU 2017. Ministry of Economic Development and Trade of Ukraine. National report of the CSB of Ukraine [Online] http://un.org.ua/images/SDGs_NationalReportUA_Web_1.pdf [Accessed: 2021-01$-17]$.

MEEP 2020. Ministry of Energy and Environmental Protection. The concept of "green" energy transition of Ukraine until 2050 [Online] https://mepr.gov.ua/files/images/news_2020/21012020/pd-

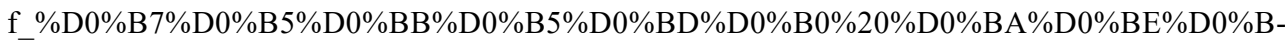
D\%D1\%86\%D0\%B5\%D0\%BF\%D1\%86\%D1\%96\%D1\%8F.pdf [Accessed: 2021-01-18].

Miśkiewicz, R. 2018. The Importance of Knowledge Transfer on the Energy Market. Polityka Energetyczna - Energy Policy Journal 21(2), pp. 49-62, DOI: 10.24425/122774.

Poullikkaset al. 2012 - Poullikkas, A., Kourtis, G. and Hadjipaschalis, I. 2012. An overview of the EU Member States support schemes for the promotion of renewable energy sources. International Journal of Energy and Environment 3, pp. 553-566.

Prokopenko, O. and Miśkiewicz, R. 2020. Perception of "Green Shipping" in the contemporary conditions. Entrepreneurship and Sustainability Issues 8(2), pp. 269-284, DOI: 10.9770/jesi.2020.8.2(16).

Ragwitz, M. and STEINHILBER, S. 2014. Effectiveness and efficiency of support schemes for electricity from renewable energy sources. Wiley Interdisciplinary Reviews: Energy and Environment 3(2), pp. 213-229, DOI: 10.1002/wene.85.

SinIŠA, F. 2020. Energy, Energetics and Energy Policy. Journal of Humanities, Arts and Social Science 4(2), pp. 187-193, DOI: 10.26855/jhass.2020.07.012.

Sotnyk et al. 2020 - Sotnyk, I., Hulak, D., Yakushev, O., Yakusheva, O., Prokopenko, O.V. and Yevdokymov, A. 2020. Development of the US electric car market: Macroeconomic determinants and forecasts. Polityka Energetyczna - Energy Policy Journal 23(3), pp. 147-164; DOI: 10.33223/ epj/127921.

State Statistics Service of Ukraine 2021a. Energy consumption based on renewable sources for 2007-2019. [Online] http://www.ukrstat.gov.ua/operativ/menu/menu_u/energ.htm [Accessed: 2021-01-10].

State Statistics Service of Ukraine 2021b. Target values of indicators for 1990-2019. [Online] http://www. ukrstat.gov.ua/ [Accessed: 2021-01-11].

State Statistics Service of Ukraine 2021c. Time series of energy balance indicators, 2019. [Online] http:// www.ukrstat.gov.ua/operativ/operativ2019/energ/drpeb/dr_u.htm [Accessed: 2021-01-11].

StOYAn, O. 2014. Legislative basis of state regulation of renewable energy of Ukraine (Zakonodavche pidgruntia derzhavnoho rehuliuvannia vidnovliuvalnoi enerhetyky Ukrainy). Bulletin of the Acade- 
my of Customs Service of Ukraine (Visnyk Akademii mytnoi sluzhby Ukrainy) 1, pp. 64-72 (in Ukrainian).

UNDP Ukraine 2020. Report «Analysis of the institutional environment and legal framework that governs public financing of the SDGs». [Online] https://www.ua.undp.org/content/ukraine/uk/home/library/ democratic_governance/analysis-of-the-institutional-environment-and-legal-framework-th.html [Accessed: 2021-01-15].

United Nations. General Assembly. Resolution adopted by the General Assembly on September 252015. [Online] https://undocs.org/en/A/RES/70/1 [Accessed: 2021-01-17].

United Nations 1987. WCED. Brundtland Report 1987. [Online] https://www.are.admin.ch/are/en/home/ sustainable-development/international-cooperation/2030agenda/un-_-milestones-in-sustainable-development/1987--brundtland-report.html\#: :text=Sustainable\%20development\%20is\%20defined\%20 as,a\%20UN\%20Conference\%20on\%20Environment [Accessed: 2020-08-15].

VIVANCO, D. 2017. Rethinking climate and energy policies: new perspectives on the rebound phenomenon. Transport Reviews 37(6), pp. 1-4. DOI: 10.1080/01441647.2017.1307878.

Olha Prokopenko, Anna Chechel, Iryna Sotnyk, Vitaliy Omelyanenko, Tetiana Kurbatova, Tetiana $\mathrm{NYCH}$

\section{Poprawa programów wsparcia państwa w zakresie zrównoważonego rozwoju energii odnawialnej na Ukrainie}

\section{Streszczenie}

Świat zmierza w kierunku wzrostu efektywności energetycznej i wykorzystywania energii ze źródeł odnawialnych i alternatywnych. Ukraina wybrała tę samą drogę. Aby sformułować rekomendacje dotyczące usprawnienia programów wsparcia państwa dla zrównoważonego rozwoju energetyki odnawialnej, autorzy przeprowadzili dogłębną analizę stanu energetyki odnawialnej na Ukrainie i jej wsparcia legislacyjnego. Zaletą tego badania jest wizualna prezentacja danych. W ten sposób autorzy przedstawili i przeanalizowali, jakie źródła energii Ukraina wykorzystuje na własne potrzeby, przedstawili bilans energetyczny Ukrainy i jego stan w 2019 roku. Stwierdzili, że rozwój energii odnawialnej jest jednym z „Celów Zrównoważonego Rozwoju Ukrainy”, które opierają się na wzorcach światowych. Autorzy wyszczególnili cele i określili wskaźniki celu, ocenili ich wartość i stwierdzili, że choć ten cel jest jednym z najważniejszych, gdyż zajmuje trzecie miejsce jeśli chodzi o liczbę nowelizacji obowiązujących przepisów, to zauważyli opóźnienia w planach i jeszcze większe opóźnienia w realizacji niektórych dodatkowych zadań. Autorzy usystematyzowali podstawy prawne funkcjonowania energetyki odnawialnej i ujawnili relacje przedmiotowo-podmiotowe tego procesu. Analiza wykazała, że doskonalenie programów wsparcia państwa na rzecz zrównoważonego rozwoju energii odnawialnej powinno opierać się na normach i standardach europejskich, ale powinno również uwzględniać specyfikę krajową. Badacze zaproponowali i opisali zasady zwiększania wsparcia państwa dla zrównoważonego rozwoju energetyki odnawialnej, które powinno opierać się na 
zapewnieniu równowagi interesów trzech głównych interesariuszy rynku energii odnawialnej: państwa, odbiorców energii i inwestorów.

SŁOWA KLUCZOWE: energia, wskaźniki bilansu energetycznego, energia odnawialna, wsparcie państwa, zrównoważony rozwój, cele zrównoważonego rozwoju 